\title{
ORIENTALISM, POSTCOLONIALISM, AND THE ACHAEMENID EMPIRE: MEDITATIONS ON BRUCE LINCOLN'S RELIGION, EMPIRE, AND TORTURE ${ }^{1}$
}

\section{HENRY P. COLBURN}

Benedetto Croce's dictum that all history is contemporary history is nowhere better exemplified than in Bruce Lincoln's 2007 book, Religion, empire, and torture: the case of Achaemenian Persia, with a postscript on Abu Ghraib. This book, despite its foregrounding of an ancient empire, is by Lincoln's own admission the product of his 'anguish and outrage concerning the American imperial adventure in Iraq'. ${ }^{2}$ But rather than criticizing American actions directly, he does so through an extended case study of the Achaemenid Persian Empire. Though Lincoln's main thesis merits much consideration, this case study is the focus of the present paper, because of the severe methodological flaws that inform it, and their potentially insidious consequences. Indeed, their insidiousness is made all the more worrisome because of the book's largely uncritical reception. The ten Anglophone reviews known to me appear in a wide range of scholarly journals, many serving academic specialties far outside of classics, ancient history, and Near Eastern studies, and only two of them even recognize some of the methodological issues. ${ }^{3}$ Even more troubling, this book was the recipient of the 2007 Frank Moore Cross Award given by the American Schools of Oriental Research. ${ }^{4}$ This organization's endorsement of such a misinformed and biased study demonstrates that despite the efforts of scholars in the field of Achaemenid studies, outdated and inappropriate ideas about the empire still persist among well informed and well meaning scholars of antiquity. This paper, then, is a series of meditations on Religion, empire, and

\footnotetext{
${ }^{1}$ I am grateful to Margaret Root, Rob Nichols, Ian Moyer, Amélie Kuhrt, Michael Crawford, and John North for feedback on an earlier draft of this paper.

${ }^{2}$ B. Lincoln, Religion, empire, and torture: the case of Achaemenian Persia, with a postscript on Abu Ghraib (Chicago 2007) 97 (hereinafter RET).

${ }^{3}$ The reviews in question are M. Gronvoll, Rhetoric and Public Affairs 12 (2009) 132-34; D. P. Gushee, Journal of the American Academy of Religion 76 (2009) 489-92; J. R. Hall, JR 88 (2008) 430-31; S. W. Hirsch, International History Review 31 (2009) 371-73; J. Hyland, The Historian 71 (2009) 589-90; M. Kozuh, 'On torture and the Achaemenids', JAOS 129 (2009) 287-93; T. K. Mikolajczak, BMCRev 2008.05.16; P. O. Skjærvø, AHR 113 (2008) 945-46; S. Staffell, The Bible and Critical Theory 5 (2009) 17; M. Stausberg, 'The lure of empire', Numen 56 (2009) 477-89; note also the brief (and ambivalent) remarks by J. Lendering, 'Let's abandon Achaemenid studies' (2008, at http://www.livius.org/opinion/opinion0014.html). Kozuh and Stausberg are the only ones that present meaningful criticisms of the book, though neither identifies the full extent of the problem. I have not to date encountered a review of the book in a language other than English.
}

${ }^{4}$ A brief citation for the award is given in the ASOR Newsletter 57.4 (2007/8) 6. 
torture, intended to elucidate ancient and modern perceptions of the empire, beginning with the methodological flaws that underlie Lincoln's account, but also including the roles played by orientalism and postcolonialism in Achaemenid historiography. The purposes of this exercise are not only to show what is problematic about Lincoln's book, but to identify the underlying causes of its problems, and to understand how such problems can be prevented in the future.

\section{Religion and torture}

The bulk of Lincoln's book is dedicated to a structuralist reading of Achaemenid royal inscriptions. ${ }^{5}$ In itself this approach is interesting for its novelty, but it is based on the implicit and unproven assumption that the Achaemenids were Zoroastrians. Lincoln claims in the book's preface that 'it is relatively inconsequential whether we regard the imperial religion as Zoroastrian in a strict and narrow sense ... or more broadly as Mazdaean', but this claim belies a heavy reliance on later, specifically Zoroastrian religious texts. ${ }^{6} \mathrm{He}$ uses these texts as parallels to his interpretations of Achaemenid ideology, many of which would otherwise have nothing else to recommend them. For example, he bookends his fifth chapter ('Microcosms, Wonders, Paradise') with references to the Zoroastrian creation myths and Pahlavi texts as a means of interpreting, among other things, Achaemenid paradeisoi. He concludes that 'the paradises that the Achaemenians built on earth were meant to offer a foretaste of the delights awaiting the righteous after death and at history's end'. ${ }^{7}$ This function is nowhere attested in any contemporary source, and is derived solely from comparisons with much later Zoroastrian material. It also ignores the extensive scholarship on the various secular functions of paradeisoi. ${ }^{8}$ Thus, despite his claim to be uncommitted on the point, Lincoln's argument relies to a significant degree on the Achaemenids being Zoroastrian after all, specifically in a manner consistent with much later Zoroastrianism; otherwise his frequent quotation of these texts serves no meaningful purpose. This view, however, is not universally accepted by scholars of the Achaemenid Empire, and requires supporting on Lincoln's part.

The question as to whether or not the Achaemenids were Zoroastrians is a vexed one. ${ }^{9}$ The only direct link between the Achaemenids and Zoroastrianism is the name of the god Auramazda, who is featured in the Achaemenid royal inscriptions. The name is related

\footnotetext{
${ }^{5}$ Kozuh, 'Torture' (n. 3 above) 290-91; and Stausberg, 'Lure of empire' (n. 3 above) 480, both point out the frailties of Lincoln's structuralist reading of the Bisitun Inscription.

${ }^{6}$ RET xiii; he quotes such texts at 18-20, 32, 48-49, 54, 56, 79, 86, 90, and 92. Stausberg, 'Lure of empire' (n. 3 above), points out various difficulties with Lincoln's deployment of these texts.

${ }^{7} \operatorname{RET} 79$.

${ }^{8}$ Stausberg, 'Lure of empire' (n. 3 above) 484; for these other functions see C. Tuplin, Achaemenid studies, Historia Einzelschriften 99 (Stuttgart 1996) 80-131. W. F. M. Henkelman, The other gods who are: studies in Elamite-Iranian acculturation based on the Persepolis Fortification tablets, Achaemenid History 14 (Leiden 2008) 427-52, has recently argued for Elamite precursors to Persian paradeisoi and notes their practical, ideological, and cultic functions, none of which are consistent with Lincoln's interpretation of them.

${ }^{9}$ Most of this discussion of Achaemenid religion is indebted to M. Garrison, 'By the favor of Ahuramazda: kingship and the divine in the early Achaemenid period', in P. P. Iossif et al. (eds.), More than men, less than gods: studies on royal cult and imperial worship, Studia Hellenistica 51 (Leuven, forthcoming). I am grateful to Mark Garrison for sharing an advance copy of this paper with me.
} 
linguistically to the name of Ahura Mazda, the foremost Zoroastrian god, where it means 'Wise Lord'. In the past this has been sufficient for many scholars to assume that the Achaemenids were Zoroastrian in a manner familiar to later practice and belief, but this notion is no longer widely accepted on account of the frailties of this link. No Zoroastrian text dates earlier than the Sasanian period (i.e. third to seventh centuries CE), when the Avesta was written, and some of the texts to which Lincoln refers were written even later, in the ninth century. Moreover, the language of the Avesta (Avestan) is an eastern Iranian dialect, meaning that the content of the Avesta is also spatially removed from the Achaemenid homeland in Fars in southwestern Iran. The date of the original composition of these texts varies considerably, and is contingent to some degree on the dates of the lifetime of Zarathustra himself, about which there is also little scholarly consensus. Thus, the use of Zoroastrian texts as evidence for, or illustrations of, Achaemenid religious belief requires continuity from the fifth and fourth centuries BCE down to the third century $\mathrm{CE}$ at the earliest. As has been noted, this continuity has been accepted easily by some scholars, most notably Mary Boyce, who has placed particular emphasis on the unbroken continuity of Zoroastrian tradition from the time of Zoroaster to the present, but as a scholarly premise it is difficult to accept uncritically. ${ }^{10}$

This difficulty is compounded by the significant quantity of evidence for Achaemenid religion that is decidedly not Zoroastrian in nature. Foremost among this are the references in the Persepolis Fortification Archive to the provisioning of cults of a wide variety of deities, including Elamite and other Iranian gods, as well as the Mesopotamian god Adad. In a recent study of these texts, Wouter Henkelman has argued convincingly that this pantheon accurately reflects the religion of the Achaemenid Persians. ${ }^{11}$ Moreover, the provisions allocated to the cult of the Elamite god Humban are significantly greater than those for that of Auramazda. In light of this evidence it is quite difficult to regard Achaemenid religion as monotheistic, let alone exclusively Zoroastrian. Likewise, without recourse to later Zoroastrian texts the Achaemenid imperial inscriptions do not actually reflect any identifiable tenet of Zoroastrianism. ${ }^{12}$ Indeed, the only contemporary references to Zarathustra himself are Greek ones. ${ }^{13}$ The end result is that there are more questions than answers about Achaemenid religion, and these uncertainties are reflected in much of the recent scholarship on religion in the empire. ${ }^{14}$ Lincoln cannot unequivocally

\footnotetext{
${ }^{10}$ Especially her paper 'The continuity of the Zoroastrian quest', in W. Foy (ed.), Man's religious quest: a reader (New York 1978) 603-19.

${ }^{11}$ Henkelman, The other gods who are (n. 8 above).

${ }^{12}$ A. Kuhrt, 'The problem of Achaemenid "religious policy", in B. Groneberg and H. Spieckermann (eds.), Die Welt der Götterbilder, ZATW Beiheft 376 (Berlin 2007) 117-42, at 120-25.

${ }^{13}$ Plato, Alcibiades I 122a; Xanthus, Lydiaca F32; W. Burkert, Babylon, Memphis, Persepolis: eastern contexts of Greek culture (Cambridge, MA 2004) 104

${ }^{14}$ E.g. J. Kellens, 'Question préalables,' in Kellens (ed.), La religion iranienne à l'époque achéménide: actes du colloque de Liège 11 decembre 1987, IA Suppl. 5 (Gent 1991) 81-86; H. Sancisi-Weerdenburg, 'Darius I and the Persian Empire', in J. M. Sasson et al. (eds.), Civilizations of the ancient Near East (New York 1995) 1035-50, at 1041-42; J. Wiesehöfer, Ancient Persia from 550 BC to 650 AD, trans. A. Azodi (London 1996) 94-101; P. Lecoq, Les inscriptions de la Perse achéménide (Paris 1997) 154-64; P. Briant, From Cyrus to Alexander: history of the Persian empire, trans. P. T. Daniels (Winona Lake 2002) 93-96, 240-54; Burkert, Babylon (n. 13 above) 101-05.
} 
link Achaemenid religious ideology with Zoroastrian practice and belief without assuming centuries of unchanged continuity between them, and this assumption can no longer be made without some justification.

Lincoln's evidence for torture on the part of the Achaemenids is more problematic. The crux of his sixth chapter, with the melodramatic title 'the Dark Side of Paradise', is a pair of passages from Plutarch's Life of Artaxerxes describing the gruesome deaths of a Persian soldier named Mithradates and an unnamed Carian, both for claiming the credit for killing the would-be usurper Cyrus. ${ }^{15}$ These passages are derived from the Persica written by Ctesias of Cnidus, a Greek doctor who spent time at the courts of Darius II and Artaxerxes II in the late fifth and early fourth centuries BCE. ${ }^{16}$ His Persica is now lost, but it is preserved in an epitome by Photius and by references to it in other authors, primarily Nicolaus of Damascus, Diodorus Siculus, and Plutarch. ${ }^{17}$ In addition to these two incidents, Ctesias also describes the death of the eunuch Masabates, whom Queen Parysatis ordered to be flayed alive for mutilating the corpse of her son Cyrus, and he alludes to the torture and gruesome deaths of several other individuals at the hands of Achaemenid royalty. ${ }^{18}$ These references to torture form the lynchpin of two important aspects of Lincoln's argument, namely the use of especially elaborate and grisly forms of torture as public spectacles in the Achaemenid Empire, and the failings of the empire in the fourth century BCE that necessitated their use. But, as will be shown below, in his discussion of Achaemenid torture Lincoln has not interrogated his sources sufficiently, with the result that he draws his conclusions on the basis of a distorted, outmoded, and prejudiced view of the empire.

Outside of Ctesias the only evidence for any torture of this kind is provided by the Bisitun Inscription, Herodotus, and Valerius Maximus. ${ }^{19}$ Valerius may be dismissed altogether, as his work dates to the first century $\mathrm{CE}$, and is quite confused about Achaemenid history. Herodotus does refer to instances of gruesome executions or other corporal punishments meted out by Achaemenid kings, but they are much less cruel and unusual than those referred to by Ctesias. They are also, as Robert Rollinger has noted, attested in other Near Eastern textual sources, albeit ones from the second and earlier first millennium BCE, whereas most of those mentioned by Ctesias do not appear in any other

\footnotetext{
${ }^{15}$ Plut. Artaxerxes 16; RET 85-87.

${ }^{16}$ M. Dorati, 'Ctesia falsario?', QS 41 (1995) 33-52, suggests that Ctesias fabricated his time at the Achaemenid court in order to lend authenticity to his written work. This argument is a difficult one to assess, but is no more extreme a position than the most sceptical approaches taken to Herodotus.

${ }^{17}$ The fragments are collected and translated by D. Lenfant, Ctésias de Cnide: la Perse, l'Inde, autres fragments (Paris 2004); L. Llewellyn-Jones and J. Robson, Ctesias' History of Persia: tales of the Orient (London 2010); and J. P. Stronk, Ctesias' Persian History, part 1: introduction, text, and translation, Reihe Geschichte 2 (Düsseldorf 2010); they all retain Jacoby's numbering of the fragments, which are utilized in this paper as well.

${ }^{18}$ F26 (= Plut. Artaxerxes 17); the other relevant fragments are F9.6, 14.34, 15.52-53, 16.58, 29b. See also the list in R. Rollinger, 'Extreme Gewalt und Strafgericht: Ktesias und Herodot als Zeugnisse für den Achaimenidenhof', in B. Jacobs and R. Rollinger (eds.), Der Achämenidenhof = The Achaemenid court: Akten des 2. Internationalen Kolloquiums zum Thema "Vorderasien im Spannungsfeld klassischer und altorientalischer Überlieferungen", Landgut Castel bei Basel, 23.-25. Mai 2007, Classica et Orientalia 2 (Wiesbaden 2010) 559-666, at 623-44.

19 B. Jacobs, 'Grausame Hinrichtungen - friedliche Bilder: zum Verhältnis der politischen Realität zu den Darstellungsszenarien der achämenidischen Kunst', in M. Zimmermann (ed.), Extreme Formen von Gewalt in Bild und Text des Altertums, Münchner Studien zur Alten Welt 5 (München 2009) 121-51.
} 
source. ${ }^{20}$ In fact torture is not attested in Near Eastern legal texts until the later Hellenistic period, when the use of a 'rack of interrogation' appears. ${ }^{21}$ The mutilation of Smerdis on the orders of Cambyses, specifically the removal of his ears, was probably a Greek invention, and it has been argued that the mutilation of Masistes' wife on the orders of Amestris actually predates the historical personages involved and originated in earlier oral tradition, the nuances of which were unclear to Herodotus by the time he encountered the story. ${ }^{22}$ Certainly there are literary features to this story that need to be given their due weight before it can be read as a straightforward historical account. Finally, in Darius' monumental trilingual inscription at Bisitun there are references to the mutilation and execution of only two of the nine rebel leaders, and it is worth noting that these are cases of high treason, which in most societies carry a penalty of the utmost severity. ${ }^{23}$ The Assyrians, for example, treated rebels in a similar manner, and in mediaeval and early modern England traitors were typically hanged, drawn, and quartered, or executed publicly in some other grisly manner. ${ }^{24}$ This does not pardon such actions on the part of Darius by any means, but it does indicate that his treatment of the rebel leaders was not exceptionally extreme by contemporary standards.

Thus Lincoln relies almost entirely on Ctesias for the elaborate and outlandish tortures that figure in his argument. This is troubling because Ctesias is not a straightforward historical source by any means. In antiquity he enjoyed a poor reputation as a historian; Plutarch, for example, accused him of being a self-aggrandizing liar. ${ }^{25}$ Many modern historians have shared this view. Felix Jacoby regarded his work as Skandalgeschichte and Arnaldo Momigliano (snidely) remarked 'There is excitement in reading Ctesias. One never knows when he will tell the truth for a change'. ${ }^{26}$ Recent attempts to revive his reputation have emphasized the literary rather than historical merits

\footnotetext{
${ }^{20}$ Rollinger 'Extreme Gewalt' (n. 18 above) 600-09.

${ }^{21}$ F. Joannès, 'Une chronique judiciaire d'époque hellénistique et le châtiment des sacrilèges à Babylone', in J. Marzahn and H. Neumann (eds.), Assyriologica et Semitica: Festschrift für Joachim Oelsner anlässlich seines 65. Geburtstag am 18. Februar 1997, Alter Orient und Altes Testament 252 (Münster 2000) 193-211.

22 Hdt. 3.69, 9.112; A. Demandt, 'Die Ohren des falschen Smerdis', IA 9 (1972) 94-101; H. SancisiWeerdenburg, 'Exit Atossa: images of women in Greek historiography on Persia', in A. Cameron and A. Kuhrt (eds.), Images of women in antiquity (London 1993) 20-33, at 28-29; see also M. A. Flower and J. Marincola, Herodotus: Histories Book IX (Cambridge 2002) 291-93.

${ }^{23}$ DB II $\S \S 32-33$; translation in A. Kuhrt, The Persian Empire: a corpus of sources from the Achaemenid period (London 2007) 145-46. Zainab Bahrani, The graven image: representation in Babylonia and Assyria (Philadelphia 2003) 149-84, has argued persuasively that mutilation had important symbolic meaning in the Near East, but that the evidence for it almost exclusively points to the mutilation of images rather than people. This does not of course preclude the latter, but she notes that modern scholarship tends to view this practice through a distinctly Greek lens and thus sees it as inherently wanton in nature.

${ }^{24}$ Briant, Cyrus to Alexander (n. 14 above) 123; W. R. J. Barron, 'The penalties for treason in medieval life and literature', Journal of Medieval History 7 (1981) 187-202.

${ }^{25}$ Plut. Artaxerxes 13.5-7. To be fair, he was also very critical of Herodotus.

${ }^{26}$ F. Jacoby, 'Ktesias', RE 11 (1922) 2032-73; A. Momigliano, Quinto contributo alla storia degli studi classici e del mondo antico, Storie e letteratura: raccolta di studi e testi 136 (Rome 1975) 929. See also Llewellyn-Jones and Robson, Ctesias' History (n. 17 above) 22-27; and Stronk, Ctesias' Persian History (n. 17 above) 31-36, for the modern reception of Ctesias.
} 
of Ctesias' work, suggesting it was meant to be novelistic rather than historical. ${ }^{27}$ The reason for this opprobrium is his lurid, trivial, and often fantastical subject matter and, in some cases, unfavourable comparisons with Herodotus. Certainly there are some real howlers in the Persica, such as his statement that the battle of Plataea preceded the one at Salamis, but there are also instances in which his information is accurate even in its details, such as in his description of the struggle for the throne between Sogdianus and Darius II, in which many of the actors named by Ctesias are also attested in contemporary Babylonian documents. ${ }^{28}$ The luridness of his subject matter may have as much to do with the nature of royal courts, or more precisely with the sorts of stories told about royal courts. In a study of the early Principate Jeremy Paterson notes 'there is no single correct account of the court: there are many narratives from many points of view, all of which have validity'. ${ }^{29}$ To wit, in the absence of an authoritative version various stories of this sort are invariably told about any royal court. Furthermore, nearly all of the material from Ctesias is preserved only in the extracts chosen by his epitomizers, especially Plutarch and Photius, whose interests affected their choices and thus the overall impression of the nature and content of Ctesias' work. ${ }^{30}$ At any rate, regardless of the ancient or modern opinions of Ctesias' merits as a historian, it is clear that his work cannot be read literally as a straightforward historical account that faithfully and accurately reproduces the events, including instances of torture, and personalities of the Achaemenid court in the early fourth century.

There is a further potential source of distortion in Ctesias' account of the Achaemenid court which needs to be identified. Heleen Sancisi-Weerdenburg, in an important deconstruction of Ctesias' text, makes an interesting observation: his Persica contains one of the earliest conceptualizations of a stereotyped and essentialized Orient, in particular an effeminate Orient, constructed in specific contrast to the Greek world. ${ }^{31}$ The acts of savagery carried out by various Achaemenid royal women demonstrate the baseness of the Persians, and the fact that women rather than men are taking actions such as these indicate that gender roles, as seen in the Greek perspective, are reversed in the Achaemenid court. It is not the first such conceptualization, and it fits a pattern of Greek (particularly Athenian) self-definition versus a barbarian 'other', which gained significant currency after the Persian Wars and is especially vivid in Aeschylus' Persians. ${ }^{32}$ As such it tells us more about the Greeks and Ctesias than it does about the Persians. Ctesias' work exhibits two tropes that are particularly characteristic of this proto-orientalism, namely a focus on

\footnotetext{
${ }^{27}$ J. P. Stronk, 'Ctesias of Cnidus: a reappraisal', Mnemosyne 60 (2007) 25-58.

${ }^{28}$ F13.28-30, 15; for the latter episode see the references in Kuhrt, Persian Empire (note 23 above) 332-33.

${ }^{29}$ J. Paterson, 'Friends in high places: the creation of the court of the Roman emperor', in A. J. S. Spawforth (ed.), The court and court society in the ancient monarchies (Cambridge 2007) 121-56, at 150.

${ }^{30}$ See Stronk, 'Ctesias' (note 27 above) 33-37; and Llewellyn-Jones and Robson, Ctesias' History (note 17 above) 40-45, for discussions of Plutarch's and Photius' uses of Ctesias.

${ }^{31}$ H. Sancisi-Weerdenburg, 'Decadence in the empire or decadence in the sources? From source to synthesis: Ctesias', in H. Sancisi-Weerdenburg (ed.), Achaemenid history 1: Sources, structures, and synthesis (Leiden 1987) 33-45

${ }^{32}$ E. Hall, Inventing the barbarian: Greek self-definition through tragedy (Oxford 1989), The theatrical cast of Athens: interactions between Greek drama and society (Oxford 2006) 184-224; see also H. SancisiWeerdenburg, 'The fifth oriental monarchy and Hellenocentrism: Cyropaedia VIII and its influence', in SancisiWeerdenburg and A. Kuhrt (eds.), Achaemenid history 2: The Greek sources (Leiden 1987) 117-31.
} 
the inherent savagery of the Persians (as exemplified by the incidents of torture he reports) and a view that after the time of Darius I, the empire entered a state of irreversible decline brought on by decadence. ${ }^{33}$ Even if his work was informed by firsthand experience, Ctesias still belonged to a Greek intellectual milieu (the Persica was composed after his return to Cnidus), and this milieu also informed how he viewed the Persians and what he wrote about them for a Greek audience. ${ }^{34}$ Moreover, as Edward Said pointed out, many of the modern orientalist authors based their written work on periods of residency in the East, but this residency did not necessarily alter or mitigate their authorial biases, and in many cases may have contributed to them. ${ }^{35}$ And even if Ctesias' portrayal of the decadence of the court of Artaxerxes II was informed by the negative propaganda of his brother, as has been suggested, Ctesias' willingness to believe it says as much about his own perceptions of the Persians as it does about the actual conditions at Persepolis or Susa. ${ }^{36}$

Both of these proto-orientalist tropes play important roles in Lincoln's argument: the role of savagery is already clear in his discussion of torture, but decline is important too, since, as he states in his denouement, in later periods the empire found it 'increasingly difficult to contain the contradiction between its discourse and its practice' ${ }^{37}$ In other words, the empire's decline is tantamount to the pursuit of paradise being stalled indefinitely, and according to Lincoln this leads to acts of enormous barbarity, such as the treatment of Mithradates. But not only is this equation not necessarily accurate (there is, as Kozuh observes in his review, always some contradiction between an empire's discourse and its practice) ${ }^{38}$ it is based on a literary trope informed by ancient Greek cultural bias rather than on historical evidence. In fact, the trope of a great founding ruler whose legacy is progressively ruined by his lesser successors is a somewhat common one in the ancient world, as exemplified by the kingdom of Israel under David, Solomon, and Rehoboam respectively, and by the Julio-Claudians and the Flavians in Rome. As such its appearance in Ctesias' Persica is yet one more reason why this author needs to be treated with caution as a historical source.

It is important to emphasize here that none of this discussion should be taken to suggest that torture was unheard of or even uncommon in the Achaemenid Empire. Even if the references to torture in Ctesias are uncertain, violence of various sorts surely must have occurred. But this is equally true of all empires, especially in antiquity. One need not look far to find instances of savagery in the Roman Empire, many of which were even

\footnotetext{
${ }^{33}$ P. Briant, 'History and ideology: the Greeks and Persian decadence', in T. Harrison (ed.), Greeks and barbarians (New York 2002) 193-210, "Alexander and the Persian empire, between "decline" and "renovation": history and historiography', in W. Heckel and L. A. Tritle (eds.), Alexander the Great: a new history (Chichester 2009) 171-88; see also B. Isaac, The invention of racism in classical antiquity (Princeton 2004) 283-98.

${ }^{34}$ For Ctesias' intellectual milieu see C. Tuplin, 'Doctoring the Persians: Ctesias of Cnidus, physician and historian', Klio 86 (2004) 305-47, especially 312-18.

${ }^{35}$ E. Said, Orientalism (New York 1978)

${ }^{36}$ D. Lenfant, 'La “décadence” du Grand Roi et les ambitions de Cyrus le Jeune: aux sources perses d'un mythe occidental?’, REG 114 (2001) 407-38.

${ }^{37}$ RET 95

${ }^{38}$ Kozuh, 'Torture' (n. 3 above) 289-90.
} 
sanctioned by Roman law. ${ }^{39}$ That is not at issue here. Rather, the issue is whether or not the Achaemenid Empire was characterized by an extraordinary level of savagery and gruesomeness in its punishments. This characterization is necessary to Lincoln's argument, but it relies on the historicity of Ctesias' account of incidents of torture, and given the difficulties surrounding the interpretation of Ctesias' work outlined above, this historicity cannot be compellingly established. It is certainly appropriate to be sceptical about the human capacity for cruelty, but there is also good reason to be sceptical about Greek representations of the Persians.

Lincoln's discussion of the Achaemenid Empire relies on the assumptions that the Achaemenids were Zoroastrian and that Ctesias' accounts of Achaemenid torture can be understood in a straightforward and literal manner. Neither of these are assumptions that scholars of the Achaemenid Empire can make unequivocally, nor do they. The consequence of their use is that Lincoln depicts the Achaemenid Empire as immutable and savage, with its noble beginnings quickly subverted by decadence and decline. This impression is at best outmoded, and at worst insidious, because these two assumptions resurrect orientalist stereotypes that scholars of the empire have long worked to overcome. Indeed, immutability and barbarity are two of the characteristics of orientalism identified by Edward Said in his famous critique, and Lincoln's use of them, however unwitting, implicates him in an orientalist agenda.

\section{Orientalism}

The study of the role of orientalism in ancient history and historiography may be something of a tired subject for many students of antiquity, but Lincoln's book demonstrates clearly its continuing relevance for contemporary scholarship, especially scholarship on the Achaemenid Empire. In Said's own words, orientalism is 'the corporate institution for dealing with the Orient - dealing with it by making statements about it, authorizing views of it, describing it, by teaching it, settling it, ruling over it: in short, Orientalism as a Western style for dominating, restructuring, and having authority over the Orient'. ${ }^{40}$ This is not the place to reexamine this multifaceted and highly controversial concept in any detail, but its salient characteristics are straightforward enough. Put simply, orientalism accentuates the differences between East and West while emphasizing the civilized, dynamic nature of the West in contrast to the savage, decadent, and static nature of the East. Said argued that this contrast is socially constructed rather than inherent, and that its purpose has been to naturalize, justify, and explain the West's domination of the East. It informs a broad range of Western thought about the East, including academic study and artistic representation, and the ethnic stereotypes and prejudices generated by it find their way, often unintentionally, into a wide variety of media and venues. Criticism of Said's thesis has been vehement and varied. In addition to cataloguing his historical errors this criticism contends that Said made undiscriminating use of literary evidence, that he was unable to demonstrate a chronological link between European imperialism and

\footnotetext{
${ }^{39}$ See R. MacMullen, Changes in the Roman empire: essays in the ordinary (Princeton 1990) 204-17; W. Rieß, 'Die historische Entwicklung der römischen Folter- und Hinrichtungspraxis in kulturvergleichender Perspektive', Historia 51 (2002) 206-26.

${ }^{40}$ Said, Orientalism (n. 35 above) 3.
} 
orientalism, that he essentialized the West in the same manner as, he argued, that the West had essentialized the Orient, and that his personal agenda clouded his objectivity. ${ }^{41}$ But none of this criticism actually counters Said's thesis in any meaningful way, and though many of his critics have cited various counterexamples, they represent exceptions rather than disproof. Likewise, claims that orientalism has been 'overcome' are equally invalid, even if orientalist stereotyping in its broadest form is now generally frowned upon. ${ }^{42}$ For example, Jack Goody has recently broached a similar topic in a study of what he perceives as the systematic attribution of historically significant innovations to periods of European history exclusively. ${ }^{43}$ The result, he argues, is a teleological approach to history whereby Europe's ascendancy is depicted as the result of a natural and inevitable progression. Though he does not refer to this as orientalism per se its effect is largely the same.

Said associated orientalism with the advent of European overseas colonization, but he also noted that it had antecedents in classical antiquity. ${ }^{44}$ Most notable is Aeschylus' Persians, first produced in $472 \mathrm{BCE}$, not long after the Persian Wars. Taking her lead from Said, Edith Hall has demonstrated that Aeschylus' portrayal of the Persians is one of the first examples of a sort of proto-orientalism. ${ }^{45}$ Aeschylus depicts the Persians as slavish, decadent, and emotional in stark contrast to the free and rational Greeks. Hall argues that this depiction is the construction of an 'other' that serves Greek selfidentification rather than accurately reflecting the lived reality of the Persians themselves. Because the Persians is tragedy rather than history this stereotyping may not raise many eyebrows, but it was not written in a vacuum and presumably had some resonance with its audience. ${ }^{46}$ Indeed, given that Athenian playwrights competed for awards it is not unreasonable to expect that the content of these plays was at least partly congruent with prevailing popular opinion. Moreover, in subsequent years historians such as Ctesias exhibited these same proto-orientalist tendencies in describing the Persians. The epilogue to Xenophon's Cyropaedia is a good example of this. ${ }^{47}$ In this section the author (who may or may not be Xenophon himself) describes how far the Persians have declined as a

${ }^{41}$ A. L. Macfie, Orientalism (London 2002) 108-45; Ibn Warraq, Defending the West: a critique of Edward Said's Orientalism (Amherst 2007). T. Harrison, Writing ancient Persia (London 2011), specifically accuses scholars of Achaemenid history of essentializing the Greek sources in this manner.

${ }^{42}$ Macfie, Orientalism (n. 41 above) 217.

${ }^{43} \mathrm{~J}$. Goody, The theft of history (Cambridge 2006).

${ }^{44}$ Said, Orientalism (n. 35 above) $56-58$.

${ }^{45}$ Hall, Inventing the barbarian (n. 32 above) 56-100, especially 99-100, Theatrical cast of Athens (n. 32 above) 184-224.

${ }^{46}$ Erich Gruen, in his recent study Rethinking the other in antiquity (Princeton 2011) 9-21, has argued that the Persians' literary aspects essentially trump any moralizing or political points made in the play. But this viewpoint completely misunderstands the points made by Hall and Said about orientalism, namely that it occurs irrespective of context or genre, and thus an author such as Aeschylus need not be attempting deliberately to make a point about the Persians in order to espouse orientalist prejudices.

${ }^{47}$ Cyropaedia 8.8; Sancisi-Weerdenburg, 'Fifth oriental monarchy' (n. 32 above) 119-28. Isaac, Invention of racism (n. 33 above) 283-98, provides a good overview of fourth-century Greek stereotypes of Persians. Gruen, Rethinking the other (n. 46 above) 53-65, again tries to argue away this passage by calling it a 'caricature of contemporary stereotypes'. If this view is correct it makes the Cyropaedia the exception that confirms the rule, i.e. Xenophon regarded his admiration for Cyrus and the Persians as exceptional, which runs contrary to Gruen's broader argument. 
people and an empire since the heyday of Cyrus the Great. Likewise, the Hippocratic treatise On Airs, Waters, and Places includes a discussion of the reasons for the 'mental flabbiness' and 'cowardice' of the Asiatic; they are attributed partly to climate and partly to the despotic form of their government. ${ }^{48}$ Aristotle expresses a similar sentiment in his Politics. ${ }^{49}$ More recently Rachel Kousser has argued that the Periclean reconstruction of the Athenian Acropolis drew heavily on the stereotype of oriental savagery in its decorative programme. ${ }^{50}$ Contemporary prejudices such as these were then incorporated into the works of later writers like Plutarch, and thus permeate the Greek sources for the Achaemenid Empire. ${ }^{51}$

The proto-orientalist prejudices of the Greeks have informed modern scholarship on the Achaemenids because until recently Greek sources were the primary evidence used for the study of the empire. Although Near Eastern sources such as the Bisitun Inscription and the Persepolis Archives have provided some counterweight to the Greek sources they provide evidence of a very different kind, and in the case of the latter they have only become available for study recently. Thus, throughout the nineteenth and much of the twentieth centuries Achaemenid history was written from a Hellenocentric viewpoint. ${ }^{52}$ Scholars from Grote and Rawlinson onwards made use of these Greek sources without recognizing the prejudices inherent in them, and as a result these prejudices became part of modern historical narratives of the empire. ${ }^{53}$ It is important to note here that the orientalism of these modern scholars was not caused by ancient prejudices; one of the key points of Said's argument is that the conceptions of East and West are contemporary social constructions rather than timeless categories. Rather, because these scholars were operating within the milieu of modern orientalism, they found the ancient prejudice to be in line with their own ideas about the differences between East and West. As Heleen Sancisi-Weerdenburg put it, "it is rather a case where two tendencies, the undefined but implicit "Orientalism" of the fourth century Greek literature and the prevalent mental attitudes of Europe-centrism in the $19^{\text {th }}$ century mutually reinforce each other. ${ }^{54}$ Though Said's critique was originally aimed at scholars of the mediaeval and modern Middle East,

${ }^{48}$ Airs, Waters, and Places 16; the translated terms are those of J. Chadwick and W. N. Mann.

${ }^{49}$ Pol. 7.1327b 18-34.

${ }^{50}$ R. Kousser, 'Destruction and memory on the Athenian Acropolis', ABull 91 (2009) 263-82.

${ }^{51}$ Herodotus' view of the Persians is considerably more complex than this. At times he seems to reflect this sort of prejudice, and at others he expresses clear admiration for the Persians. This is not the proper venue to consider the matter in detail; for a recent, succinct overview see E. S. Gruen, 'Herodotus and Persia', in E. S. Gruen (ed.), Cultural identity in the ancient Mediterranean (Los Angeles 2011) 67-85.

${ }^{52}$ Sancisi-Weerdenburg, 'Fifth oriental monarchy' (n. 32 above), 'Achaemenid history: from Hellenocentrism to Iranocentrism', in G. Gnoli and A. Panaino (eds.), Proceedings of the first European conference of Iranian studies, Serie orientale Roma 67 (Rome 1990) 253-59.

${ }^{53}$ This is evident in the various examples collected and discussed by P. Briant, 'Milestones in the development of Achaemenid historiography in the era of Ernst Herzfeld', in A. C. Gunter and S. R. Hauser (eds.), Ernst Herzfeld and the development of Near Eastern studies (Leiden 2005) 263-80; A. Lianeri, 'The Persian Wars as the "origin" of historiography: ancient and modern orientalism in George Grote's History of Greece', in E. Bridges et al. (eds.), Cultural responses to the Persian Wars: antiquity to the third millennium (Oxford 2007) $331-53$.

${ }^{54}$ Sancisi-Weerdenburg, 'Fifth oriental monarchy' (n. 32 above) 130. T. Harrison, Writing ancient Persia (n. 41 above) 122 , seems to miss this point entirely. 
it has had clear applicability to those studying the Achaemenid Empire as well. Lincoln's book is a case in point: he recognizes explicitly the bias inherent in many of the Greek sources, yet he ends up reproducing that same bias himself. ${ }^{55}$

It is worth noting here that the role played by classics in the formation, validation, and maintenance of European colonialism, especially in the nineteenth century, has also affected significantly modern scholarly views of Achaemenid imperialism. Just as orientalism served to naturalize Western domination of the East, classics privileged the study of Greece and Rome, both of which engaged in colonization and imperialism of various sorts, making them exemplars for contemporary states and empires ${ }^{56}$ European (and American) colonizers saw themselves as the successors to the Greeks and Romans, not only culturally and linguistically, but also politically. But, because of the ancient and modern prejudices articulated above, the Achaemenid Empire was rarely viewed as exemplary in this manner. It was sometimes viewed as a great empire in comparison with a decadent and corrupt modern Iranian shahdom, and, although the figure of Cyrus the Great was much admired at various points in time, this admiration was due as much to the reception of Xenophon's Cyropaedia in Renaissance Italy and later periods as it was to any aspect of the historical figure. ${ }^{57}$ This preference for Greco-Roman imperialism resulted in the creation of a double standard that persists even in some modern scholarship, according to which this classical imperialism can be a sign of achievement, whereas Achaemenid imperialism is necessarily oppressive and loathsome. For example, Lincoln and other scholars have no compunctions about describing Achaemenid torture in gruesome detail, despite the unreliable nature of the evidence for it. ${ }^{58}$ At the same time the most egregious act of Athenian imperialism, the slaughter to a man of the Melians in 416/15 BCE, has elicited bewilderment and confusion on the part of many classicists, and in at least one (somewhat disturbing) case even an apology for Athenian behaviour. ${ }^{59}$ Nor is this double standard exclusive to the field of classical studies. Egyptologists have long regarded Egyptian imperial expansion in the New Kingdom with interest and favour; at the same time their attitudes towards the period of Achaemenid rule in Egypt range from hostile to dismissive. Studies of this period tend to take the somewhat contradictory view that on the one hand this rule was oppressive and harsh, and that all Egyptians with few

${ }^{55}$ RET 14

${ }^{56}$ I cite here only the recent work on this subject which has most informed my thinking: P. Vasunia, 'Hellenism and empire: reading Edward Said', Parallax 9.4 (2003) 88-97, 'Greater Rome and Greater Britain', in B. Goff (ed.), Classics and colonialism (London 2005) 38-64; D. J. Mattingly, Imperialism, power, and identity: experiencing the Roman empire (Princeton 2011); see also the papers collected in M. Bradley (ed.), Classics and imperialism in the British empire (Oxford 2010).

${ }^{57}$ Harrison, Writing ancient Persia (n. 41 above) 101-02; H. Sancisi-Weerdenburg, 'Cyrus in Italy, from Dante to Machiavelli: some explorations of the reception of Xenophon's Cyropaedia', in Sancisi-Weerdenburg and J. W. Drijvers (eds.), Achaemenid history 5: the roots of the European tradition (Leiden 1990) 31-52.

${ }^{58}$ RET 85-96; Jacobs, 'Grausame Hinrichtungen' (n. 19 above).

59 Thuc. 5.116; A. B. Bosworth, 'The humanitarian aspect of the Melian dialogue', JHS 113 (1993) 30-44. Chester G. Starr, in 'Athens and its empire', CJ 83 (1988) 114-23, was an early critic of Athenian imperialism, albeit one whose criticism has been largely ignored; see now P. Liddell, 'European colonialist perspectives on the Athenian power: before and after the epigraphic revolution', in J. Ma et al. (eds.), Interpreting the Athenian empire (London 2009) 13-42; and L. Kallet, 'Democracy, epigraphy and empire in the twentieth century', in Interpreting the Athenian empire 43-66. 
exceptions (who are labelled 'collaborators', a distinctly pejorative and largely anachronistic term) were ready to revolt at a moment's notice, and, on the other, that the Egyptians were largely unaffected by it. ${ }^{60}$ These views are not completely mutually exclusive, but they do require some effort to reconcile, and the evidence for each is generally scant and circular. Moreover, it has been pointed out that Egyptologists typically only date material remains to the Achaemenid period if compelled to do so by epigraphic evidence. ${ }^{61}$ This tendency in turn furthers notions about the oppressive yet ephemeral nature of Achaemenid imperialism in Egypt. This Egypto-centrism is informed by the same factors that create similar distortions in the work of classicists.

The end result of this historical political baggage is that orientalist stereotypes continue to underlie many studies of the Achaemenid Empire, of which Lincoln's is a prime example. The persistence of these stereotypes demonstrates the continuing relevance and importance of orientalism as an interpretive framework for Achaemenid historiography. As has been noted above, orientalism cannot be overcome; it can only be recognized in such a way that its impact on the study of the empire can be understood and mitigated as well as possible. But given that such biases exist in both ancient and modern scholarship on the empire (despite recent apologies for both) they will never actually disappear. ${ }^{62}$ The paradox of Lincoln's book is that his objective is clearly anti-imperial and postcolonial in nature, yet in making his point, which is to condemn modern American imperialism, he ends up reifying the orientalist stereotypes that inform such imperialism. He makes the Achaemenids out to be oriental savages whose religious ideology contributed to their savagery. In essence he puts orientalism in the service of postcolonialism. This paradox suggests that it was not at all Lincoln's goal to bolster and reiterate these stereotypes, but he has nevertheless done so, and in doing so has undermined the thesis of his book (since his depiction of the Persians is unsettlingly analogous to certain representations of the targets of American military activity). ${ }^{63}$ He has also undermined some thirty years of scholarship on the Achaemenid Empire by scholars who have worked assiduously to counter these stereotypes.

\section{Postcolonialism}

The tension between orientalist stereotyping and the postcolonial critique of imperialism that characterizes Lincoln's book demonstrates a fundamental paradox in the study of the Achaemenid Empire. On the one hand the work of Heleen Sancisi-Weerdenburg and the other participants in the Achaemenid History Workshops in the 1980s to overcome orientalist prejudices in previous scholarship were (in most cases implicitly) postcolonial

\footnotetext{
${ }^{60}$ Contrast, for example, the views of H. Sternberg-el Hotabi, 'Politische und sozio-ökonimsiche Strukturen im perserzeitlichen Ägypten: neue Perspketiven', Z̈̈S 127 (2000) 153-67; and J. H. Johnson, 'The Persians and the continuity of Egyptian culture', in H. Sancisi-Weerdenburg et al. (eds.), Achaemenid history 8: continuity and change (Leiden 1994) 149-59.

${ }^{61}$ D. A. Aston, 'Dynasty 26, Dynasty 30, or Dynasty 27? In search of the funerary archaeology of the Persian period', in A. Leahy and J. Tait (eds.), Studies on ancient Egypt in honour of H. S. Smith, Occasional Publications 13 (London 1999) 17-22.

${ }^{62}$ Gruen, Rethinking the other (n. 46 above); Harrison, Writing ancient Persia (n. 41 above).

${ }^{63}$ For such representations see e.g. J. Raban, 'Emasculating Arabia', The Guardian, 13 May 2004.
} 
in nature. ${ }^{64}$ After all, Said's critique of orientalism is one of the founding texts of academic postcolonialism. ${ }^{65}$ On the other hand, one of the recent intellectual currents in the study of Roman imperialism is the recognition that such imperialism was potentially traumatic and harmful to the subjects of the empire, an approach in keeping with postcolonial thought. ${ }^{66}$ Both of these positions are important for the study of the empire (and for all non-European empires). The question, then, is how we might study the Achaemenid Empire in a manner that rehabilitates it in the face of the biases of previous and current scholarship but at the same time recognizes the potentially harmful effects of imperialism. One answer to this question is that, since earlier modern scholarship on the empire emphasized its oppressive and despotic nature, such postcolonial concerns have already been addressed. To some degree this is the approach taken implicitly in Lincoln's book. ${ }^{67}$ It is, however, inadequate, because it is based as much on bias as on any sort of evidence. As such it does both a disservice to the Achaemenids themselves, and to the subjects of the empire, since it misrepresents the experiences of both.

A second answer is to recognize that Achaemenid imperialism was experienced differently by everyone in the empire. David Mattingly refers to the 'discrepant experiences' of people living throughout the Roman Empire, arguing that 'we need to break free from the tendency to see the colonial world as one of rulers and ruled (Romans and natives) and explore the full spectrum of discrepancy between these binary oppositions' ${ }^{68}$ In the simplest terms this means that the 'winners' and 'losers' in any colonial situation do not necessarily divide evenly along ethnic, national, or racial lines. Sometimes there were tangible benefits to being part of an empire, such as the economic growth in Roman North Africa, and sometimes the experience of the colonisers was not a positive one, ranging from the disastrous, such as at Isandlwana or in the Teutoberg Forest, to the pathetic, as encapsulated by George Orwell's experience as a police officer in Burma and recounted in his classic essay 'Shooting an elephant'. ${ }^{69}$ This distinction between winners and losers was not a fixed one. These statuses were no doubt changeable according to circumstances, and were at times anyway constructed actively to achieve specific goals.

This approach can be illustrated by some examples from Egypt during the period of Achaemenid rule there (c. 525-404 BCE, Manetho's $27^{\text {th }}$ Dynasty). Perhaps the most famous example of an Egyptian winner is Udjahorresnet, known from his naophorous statue in the Vatican and his shaft tomb at Abusir. In the autobiographical inscription on his statue he lists his various positions under the Saite pharaohs, namely naval commander of some kind, and under the successive Achaemenid rulers, primarily chief physician. ${ }^{70}$ He also claims to have composed the royal titulary for Cambyses, to have been resident at the court of Darius for a time, and to have received gold ornaments as marks of royal

\footnotetext{
${ }^{64}$ E.g. Sancisi-Weerdenburg, 'Fifth oriental monarchy’ (n. 32 above) 131.

${ }^{65}$ R. J. C. Young, Postcolonialism: an historical introduction (Oxford 2001) 383.

${ }^{66}$ E.g. Mattingly, Imperialism (n. 56 above).

${ }^{67}$ Harrison, Writing ancient Persia (n. 41 above) is another example of such an approach.

${ }^{68}$ Mattingly, Imperialism (n. 56 above) 29, 213-18.

${ }^{69}$ In his Shooting an elephant and other essays (London 1953) 1-10. For North Africa as a 'landscape of opportunity' see Mattingly, Imperialism (n. 56 above) 146-66.

${ }^{70}$ Translation in Kuhrt (n. 23 above) 117-22, with bibliography.
} 
favour (and there are bracelets of Achaemenid type on the statue's wrists). If this biography is accurate, Udjahorresnet seems to have been quite successful as a result of Achaemenid rule. After serving both Cambyses and Darius he returned to his hometown of Sais a man of great local importance. Yet it is interesting to note that in this same inscription he refers to how he saved the people of Sais from 'the very great disaster, which befell the entire land. There was not its like in this land'. This disaster is typically interpreted as being Cambyses' invasion. If so, Udjahorresnet's inscription is a good example of the range of discrepant experiences in Achaemenid Egypt: some people, like Udjahorresnet, had access to new opportunities, while others simply endured the trauma of invasion and conquest. Udjahorresnet's assistance to the people of Sais suggests he had (or was at least cognisant of) both experiences. Similarly, there were clear beneficiaries of Achaemenid imperialism amongst the residents of Ayn Manawir in the Kharga Oasis. The town was founded on a previously uninhabited site in the first half of the fifth century $\mathrm{BCE}$. Its establishment was made possible by the construction of a system of qanats, an Iranian irrigation technology whose spread is typically associated with the expansion of the Achaemenid Empire. The temple's archives still await full publication, but preliminary research suggests a thriving local economy, one with sufficient links to the Mediterranean that some transactions were recorded using a Greek rather than an Egyptian weight standard for silver. ${ }^{71}$ Yet at the same time it is important to note that these oases of the western desert served as places of exile throughout Egyptian history. ${ }^{72}$ It is not known whether these farmers were pioneers in search of new opportunities in the oasis or deportees forcibly relocated from the Nile Valley, but some of them, either the farmers themselves or the priests at the temple, did benefit from Egypt's new position as a part of the Achaemenid Empire.

It is also important to recognize that imperialism is not necessary for oppression and other unpleasant situations to exist. In the case of Egypt this is nicely illustrated by the socalled Petition of Petiese, a Demotic document found at El-Hibeh. In it the elderly priest Petiese relates the abuses he suffered at the hands of his fellow priests and the failure of the royal bureaucracy in Memphis to take action on his behalf. ${ }^{73}$ The date of this narration is $513 \mathrm{BCE}$, i.e. during the period of Achaemenid rule, but the events he relates all occurred during the preceding native Egyptian Saite dynasty. The historicity of this document is difficult to assess, since it includes various literary features, including hymns. But it was found with other, non-literary documents that refer to other members of Petiese's family; thus presumably it makes reference to actual people, if not actual

\footnotetext{
${ }^{71}$ See M. Chauveau, 'Irrigation et exploitation de la terre dans l'oasis de Kharga à l'époque perse', CRIPEL 25 (2005) 157-63, with references to further bibliography. This is not to say that such links were automatically beneficial; Ian Morris, 'Mediterraneanization', MHR 18.2 (2003) 30-55, at 46-50, has argued that 'Mediterraneanisation' (like imperialism and globalization) creates both winners and losers.

${ }^{72}$ E. F. Morris, 'Insularity and island identity in the oases bordering Egypt's great sand sea', in Z. Hawass and S. Ikram (eds.), Thebes and beyond: studies in honor of Kent Weeks, ASAE Cahier 41 (Cairo 2010) 129-44, at 134-36.

${ }^{73}$ P. Ryl. Dem. 9; for this text see G. Vittmann, Der demotische Papyrus Rylands 9, Ägypten und Altes Testament 38 (Wiesbaden 1998).
} 
events. ${ }^{74}$ The ostensible purpose of the document is to record the abuses against Petiese so that he could attempt once again to seek redress for them from the court at Memphis, this time from the Achaemenid satrap. This suggests that the document's author, whether it was Petiese himself or an unknown writer, found it plausible that the Achaemenid rulers of Egypt would be receptive to such an appeal. Or perhaps he observed no meaningful difference between the administrators and bureaucrats of the $26^{\text {th }}$ Dynasty and those of the $27^{\text {th }}$. At any rate the abuses suffered by Petiese in P. Ryl. Dem. 9 are indicative of the power imbalances that exist in all places and times. We need to be wary of painting too rosy a picture of any political system or institution, whether it is the result of foreign imperialism or native rule.

A third answer is to place the empire in a broader comparative perspective. This helps to elucidate implicit assumptions about the nature of the empire by setting them up in comparison with better known examples and identifying commensurable aspects. For example, in a forthcoming study I develop an estimate for communication speed in the Achaemenid Empire based on comparative data from the American Pony Express. ${ }^{75}$ This estimate suggests that under ideal conditions communication was notably faster in the Achaemenid Empire than in the Roman. Communication speed can be used as a proxy for interconnectivity, and as such is an important precursor for understanding the potential impact of Achaemenid rule on local populations. If, for example, the empire was highly decentralized its ability to exploit and oppress its subjects was presumably limited. In this respect comparison with other empires such as Rome provides an important benchmark which can be used to develop parameters for understanding the nature of the Achaemenid Empire. Another example is provided by the recent Cambridge economic history of the Greco-Roman world. In the chapter on the Achaemenid Empire, an estimate of $8 \%$ is given for the tax rate in Mesopotamia. This estimate is tenuous, but it nevertheless permits comparison with other empires. In the same volume a tax rate of about $10 \%$ is suggested for the Roman Empire, a rate which scholars agree must have been low so as to not compete too much with private rents. ${ }^{76}$ If it was indeed the case that the tax rate was lower in the Achaemenid than in the Roman Empire, the assumption that the former was oppressive (at least financially) requires reassessment. These numbers are of course very much subject to debate, but the point is that, so long as their intellectual underpinnings are made explicit, estimates of this sort can help undermine orientalist stereotyping, and also provide a sound basis for considering how oppressive or lenient any particular empire may have been.

These three answers are only suggestions about how to accommodate postcolonial concerns in Achaemenid historiography. Their purpose is not only to help avoid the problems presented by Lincoln's book, but also to put the study of the empire more in line with the scholarship on other ancient empires, most notably Rome. In doing so we need to

\footnotetext{
${ }^{74}$ See most recently the discussion by C. Traunecker, 'Les deux enfants du temple de Teudjoï (à propos du P. Rylands IX)', in L. Gabolde (ed.), Hommages à Jean-Claude Goyon: offerts pour son 70e anniversaire, Bibliothèque d'Étude 143 (Cairo 2008) 381-96, who attempts to reconcile the document's incongruous features.

${ }^{75}$ H. P. Colburn, 'Connectivity and communication in the Achaemenid Empire' (unpublished paper under submission)

${ }^{76}$ P. R. Bedford, 'The Persian Near East', in W. Scheidel et al. (ed.), The Cambridge economic history of the Greco-Roman world (Cambridge 2007) 302-29, at 326-28; E. Lo Cascio, 'The early Roman Empire: the state and the economy', The Cambridge economic history of the Greco-Roman world 619-47, at 622-25.
} 
be careful not to obscure the empire's uniqueness. Its ideology of inclusion was a clear departure from that of earlier Near Eastern empires, and though the degree to which this ideology aligned with actual conditions is unclear it is important that the possibility that this was a different sort of empire should not be ruled out a priori. But it is clear that the application of postcolonial theory to the study of the Achaemenid Empire has the potential to be profitable and stimulating, and Lincoln's book is a clear example of why it needs to be done, and why it needs to be done judiciously.

\section{Contemporary history}

As Lincoln himself admits, his book is really about recent American activities in Iraq. ${ }^{77}$ The extended discussion of the Achaemenid Empire is only meant to be a lengthy ancient case study that illustrates Lincoln's real point, which is the subject of the postscript on Abu Ghraib. This raises the question of how the past can and should be used to comment on the present. This is, of course, an enormous topic, and its treatment here cannot consist of anything more than personal reflections; it has no pretensions to comprehensiveness. But it is nevertheless worth considering the role of contemporary events in the study of antiquity, since such events so clearly informed the writing of this book. On the one hand, Lincoln's premise that a historical case study can have important resonances for the present is an important one. Few students of ancient history (I assume) would contend that the past is entirely irrelevant to the present, even if there are major differences between them. But studies that make that relevance explicit are often regarded as unsettling or unreliable, because the author's apparent scholarly objectivity has been compromised in favour of an ulterior motive. To my mind the view that the past should never be utilized to comment on the present is a decidedly naïve one. First, it already happens all the time, often on the part of people who are not experts in the relevant field. Secondly, the concept of scholarly objectivity is not a straightforward one. It relies on a Rankean notion of historical objectivity, one that is increasingly criticized as untenable and unrealistic. ${ }^{78}$ As a result scholars need to be up front about what informs any particular study, regardless of whether the goal of that study is to make a point about the past or about the present. Indeed, in many respects scholars who do use the past to comment on the present are much more transparent in this way. Certainly this is the case in Lincoln's book; his frankness about his agenda makes the ideas, preconceptions, and motives that inform his work clear for the reader. To some degree I am even grateful to him for pointing out in so public a venue the continuing importance of the subject of my own research. The sheer variety of journals in which this book was reviewed demonstrates how much it resonated with people across a broad spectrum of academic subfields, and even if the book itself is problematic, Lincoln's attempt to show the importance of the past for the present, not to mention his condemnation of American torture in Iraq, is highly praiseworthy.

But there is (to commandeer the title of one of Lincoln's chapters) a 'dark side of paradise'. Since the contemporary is (by definition) fleeting, there is an added onus on scholars using the past to comment on the present to do so in a manner that is

${ }^{77}$ RET 97.

${ }^{78}$ My thinking on this matter owes much to E. A. Clark, History, theory, text: historians and the linguistic turn (Cambridge, MA 2004). 
intellectually robust and methodologically transparent. This is because once the topical parts of such a study become outdated all that remains is the discussion of the past. In Lincoln's case once the incidents of Abu Ghraib are no longer so vividly fixed in the public consciousness, only his flawed discussion of the Achaemenid Empire will leave a lasting impression with most readers. For example, one reviewer claims: 'but it would be far too easy to dismiss Lincoln's strategy of using Achaemenian [sic] Persia as a straw man to disguise a critical analysis of the foreign policy of the Bush administration. For this would not do justice to the insightful discussion of Achaemenian religious politics that Lincoln unfolds' ${ }^{79}$ This remark exemplifies perfectly the danger posed by this book, even for bona fide academics specializing in adjacent fields, let alone for general readers. Lincoln's book is especially problematic because it requires a savage, decadent, and declining Achaemenid Empire in order to make its point about America, one which is simply not supported by the evidence he musters. Yet it is this vision of the empire that will be this book's legacy. In the end Religion, empire, and torture, despite the power and relevance of its thesis for the present, does a disservice to the past and to the future.

University of Michigan

${ }^{79}$ Stausberg, 'Lure of empire' (n. 3 above) 478-79. 